\title{
The Effect Of Mangrove Leaf Extract Dosage Sonneratia Alba On Hela Cell Viability
}

\author{
Fitria Devi Suryaningrum*, Bambang Budi Sasmito \\ Faculty of Fisheries and Marine Sciences Universitas Brawijaya. \\ *Corresponding author: fitria_d@student.ub.ac.id
}

\begin{abstract}
Cervical cancer is caused due to infection from the Human Papilloma Virus (HPV) which attacks the sexually active female reproductive organs. Treatment is carried out alternatively using natural ingredients such as mangroves. Sonneratia alba is a type of mangrove plant that has been used in alternative medicine because of its potential as an anticancer. This study aims to determine the effect of Sonneratia alba mangrove extract on heLa cell viability. The Sonneratia alba leaf powder was extracted using stratified maceration. The solvents used include n-hexane, ethyl acetate, and ethanol. The results showed that the LC50 value was $3.59 \mathrm{ppm}$, this means that the ethyl acetate extract has toxic properties. Phytochemical test results of Sonneratia alba leaf extract contain alkaloid compounds, steroids / triterpenoids, and tannins. The results of the test yield extract were $12.60 \%$, extract water content was $21.24 \%$, and total phenol was 504.08 $\mathrm{mg}$ / g GAE Test The results of the LC-MS test resulted in the suspicion of compounds including diosmetin, caffeine, and turmeron. The ethyl acetate extract of Sonneratia alba leaves was cytotoxic against heLa cell viability with the resulting IC50 value of $478.630 \mu \mathrm{g} / \mathrm{mL}$.
\end{abstract}

\section{Keywords: cervical cancer, Sonneratia alba, extract, hela cell, and cytotoxic}

\section{INTRODUCTION}

Cancer is a disease caused by the condition of cells that have abnormal attitudes in which cells in the body experience growth out of control, so that they can attack other normal cells and form new cancer cells (Gustiana et al., 2014). One type of cancer that attacks women is cervical cancer. This cancer is caused by the Human Papilloma Virus (HPV) infecting the reproductive organs of women who are sexually active. Factors that can affect cervical cancer include a history of cervical cancer, use of contraceptives, sexual intercourse, and smoking (Rio \& Suci, 2017). Cervical cancer is the leading cause of death in developing countries. There are 510,000 cases of cervical cancer sufferers and as many as 288,000 have died due to the cancer (Ariani, 2015).

Cancer treatment has been widely used chemotherapy. Chemotherapy is done with the aim of attacking cancer cells and is carried out using high doses of drugs. Drugs used in chemotherapy include cytostatic drugs such as taxol, blemycin, doxorubicin, 5-flurouracil, chlorambucil, tioterpa, indole alkaloids such as vinblastine and vincristine. The side effect of using these drugs is that they can kill normal cells 
that are actively proliferating such as hair, skin, sex glands, and gastrointestinal cells. In addition, the use of drugs with high doses can cause cancer cells to be more resistant to drugs (Mahfur, 2016). Thus, alternative treatment is carried out using natural ingredients that are more effective and selective in killing cancer cells without attacking other normal cells (Harwoko \& Utami, 2010).

Mangrove Sonneratia alba is a type of mangrove plant that contains bioactive

\section{METHODS}

\section{Research Time and Place}

The research was carried out in MarchOctober 2020 at the Water Products Science Technology Laboratory (Fisheries Product Engineering Division), Faculty of Fisheries and Marine Sciences, Brawijaya University, Malang. Central Police Forensic Laboratory, South Jakarta and Central Laboratory for Steam Cell Development, Airlangga University, Surabaya.

\section{Tools and materials}

The tools used in this research are oven, digital scale, measuring cup, beaker glass, rotary evaporator, glass bottle, Erlenmeyer, funnel, spatula, porcelain cup, cruhtable pliers, desiccator, test tube, test tube rack, measuring flask, spatula, pipette drops, measuring pipette, suction bulb, vial, UV-Vis spectrophotometer, aquarium aerator, serological pipette, LC-MS instrument, cryo tube, Laminar Air Flow, water bath, $\mathrm{CO} 2$ gas cylinder, interved microscope, 0.2 $\mu \mathrm{m}$ filter, spet, well, centrifuge, micropipette, multiple disk, and reader analysis. compounds such as alkaloids, flavonoids, steroids/triterpenoids, saponins, and tannins that have potential as anticancer (Musa et al., 2019). Plants that have the potential as anticancer will direct compounds that play a role in cell growth regulatory genes. Sonneratia alba was developed as an anticancer by knowing the cytotoxic activity of Sonneratia alba mangrove leaf extract on the viability of $\mathrm{HeLa}$ cells by determining the $\mathrm{IC}_{50}$ value.

The main ingredients used were Sonneratia alba mangrove leaves obtained from the Clungup Mangrove Conservation (CMC) area, Sendang Biru, Malang, East Java. While the materials used in the test were n-hexane solvent, ethyl acetate solvent, ethanol solvent, filter paper, bottles, plastic wrap, label paper, aluminum foil, aquades, $\mathrm{H} 2 \mathrm{SO} 4, \mathrm{HCl}$, Meyer reagent, $1 \% \mathrm{FeCl}$, magnesium powder, anhydrous acetic acid, label paper, ascorbic acid, seawater, Artemia salina, cultured heLa cells, MC media, and heLa cell staining.

\section{Research methods}

The method in this study is an experimental method using Completely Randomized Design (CRD). Then analyzed using ANOVA (Analysis of variance) followed by Tukey's test. 


\section{Research design}

The research design was carried out using Sonneratia alba leaves that had been dried. The research was carried out with treatment doses of 2000 ppm, 1000 ppm, 500 ppm, 250 ppm, and $125 \mathrm{ppm}$. Then processing was carried out using a Completely Randomized Design (CRD).

Table 1. Research Experiment Design

\begin{tabular}{cccc}
\multirow{2}{*}{ Sample } & \multicolumn{3}{c}{ Loop } \\
\cline { 2 - 3 } & 1 & 2 & 3 \\
\hline P1 $(2000 \mathrm{ppm})$ & $\mathrm{P} 1.1$ & $\mathrm{P} 1.2$ & $\mathrm{P} 1.3$ \\
P2 (1000 ppm) & P2.1 & P2.2 & P2.3 \\
P3 (500 ppm) & P3.1 & P3.2 & P3.3 \\
P4 (250 ppm) & P4.1 & P4.2 & P4.3 \\
P5 (125 ppm) & P5.1 & P5.2 & P5.3
\end{tabular}

\section{Research procedure}

\section{a) Sample Preparation}

Sonneratia alba mangrove leaves were washed using running water and dried at room temperature (6-7 days) to reduce water content. Then it is ground using a grinding machine until it becomes powder and sieved.

\section{b) Sample Extraction}

Extraction of samples using multilevel maceration method with n-hexane, ethyl acetate, and ethanol as solvents. The extraction process begins with soaking Sonneratia alba mangrove powder in $\mathrm{n}$-hexane solvent in a ratio of $1: 2(\mathrm{w} / \mathrm{v})$ for $2 \times 24$ hours. Then the filtrate from the immersion is evaporated using a rotary evaporator. As for the residue, re-soaking was carried out using ethyl acetate solvent in a ratio of $2 \times 24$ hours. The filtrate from the immersion is evaporated using a rotary evaporator. Furthermore, the residue from the immersion was added with ethanol solvent for $2 \times 24$ hours. The filtrate from the immersion is evaporated using a rotary evaporator. After that, the extraction results from each solvent are obtained.

\section{c) Extract Yield Calculation}

The yield calculation is the amount of the sample extract from the extraction. Calculation of yield results using the formula:

$$
\% \text { Yield }=\frac{\text { Final Extract weight }(\mathrm{g})}{\text { Initial sample weight }} \times 100 \%
$$

\section{d) Water level test}

The water content test is in accordance with SNI 2354.2:2015 using the gravimetric method. The extract was weighed as much as 2 grams, then put it in a porcelain dish whose dry weight was known. Put it in the oven for $16-24$ hours at $105^{\circ} \mathrm{C}$. then remove from the oven and put in a desiccator for 30 minutes. Reweigh the cup and sample as final weight. Calculation of \% water content using the formula:

$\%$ Water content : $\frac{\mathrm{B}-\mathrm{C}}{\mathrm{B}-\mathrm{A}} \mathrm{X} 100 \%$

Information :

A : empty cup weight (g);

B : weight of the cup and sample before being in the oven, $(\mathrm{g})$;

$\mathrm{C}$ : weight of the cup and sample after being in the oven, (g).

\section{e) Phytochemical Test}

\section{Flavonoid}

Sonneratia alba leaf extract as much as 0.05 grams was put into a vial. $0.1 \mathrm{mg}$ of $\mathrm{Mg}$ powder and $0.4 \mathrm{ml}$ of amyl alcohol were added. Then observe the changes until a dark red, yellow to orange color is formed. 


\section{Alkaloid}

Sonneratia alba leaf extract as much as 0.05 grams was put into a vial. Then add a few drops of $2 \mathrm{~N}$ sulfuric acid and Meyer's reagent. Then observe the changes until a yellowish white precipitate is formed.

\section{Steroid/Triterpenoid}

Sonneratia alba leaf extract as much as 0.05 grams was put into a vial. Add $2 \mathrm{ml}$ of chloroform. Then, add 10 drops of acetic anhydride and 3 drops of sulfuric acid. Observe the changes that occur until a blue or green color is formed for steroids and orange or purple for triterpenoids.

\section{Tannin}

Sonneratia alba leaf extract as much as 0.05 grams was put into a vial. Then add $3-1 \%$ $\mathrm{FeCl}_{3} 4$ drops. Observe the change until a blackish blue color is formed.

\section{Saponin}

$1 \mathrm{ml}$ of Sonneratia alba leaf extract was put into a vial. Then added $5 \mathrm{ml}$ of hot distilled water. Shake vertically for 10 seconds. Observe the changes until 1-10 $\mathrm{cm}$ high foam is formed for 10 minutes.

\section{f) Toxicity Test Using the BSLT Method} Metode

\section{Preparation of Artemia salina}

Hatching is done by immersing 1 gram of Artemia saline eggs into $1 \mathrm{~L}$ of seawater in a bottle. Then aerated for 48 hours.

\section{Test Solution Preparation}

A total of 200 grams of Sonneratia alba leaf extract was dissolved in $100 \mathrm{ml}$ of seawater, so that an initial concentration of
2000 ppm was obtained as the mother liquor. Subsequently, dilution was carried out to obtain concentrations of 1000,100, 10, and 1 ppm. The solution used as a control was carried out without the addition of extract.

\section{Toxicity Test}

Each concentration of the solution was taken as much as $5 \mathrm{ml}$, then put into a vial. Enter 10 Artemia salina tails that have been aged 24 hours. This study was conducted for 24 hours, then observed the number of dead Artemia salina.

\section{g) Total Phenol Test}

A total of 0.01 grams of Sonneratia alba leaf extract was put into a $10 \mathrm{ml}$ volumetric flask and $10 \%$ methanol was added to the mark. Then filter and take the filtrate as much as $0.5 \mathrm{ml}$. Add $2.5 \mathrm{ml}$ of Folin-Ciocalteau $10 \%$ reagent. Then incubate at room temperature for 1 hour. Then measure the absorbance value using a UV-Vis spectrophotometer with a wavelength of $760 \mathrm{~nm}$. Then put it in the formula:

Total phenol $=\frac{x(\text { ppm }) \cdot V \text { sample }(\mathrm{ml}) \cdot F P}{\text { sample }(\text { gram })}$

h) Cytotoxicity Test with MTT Assay Method Metode

\section{HeLa Cell Preparation}

The initial process is freezing thawing by removing the cells from the cryo tube from the nitrogen tank at $-80^{\circ} \mathrm{C}$ and put into Laminar Air Flow to avoid contamination. Previously spray $70 \%$ alcohol on the equipment to be used. Then the cryotube is thawed until the ice contained in it melts. Then do as much as 10 
$\mathrm{ml}$ using RPMI medium. Centrifugation for 5 minutes at 3000 RPM to separate heLa cells with RPMI media. Next, transfer the contents of the cryotube to a culture plate with a diameter of $9 \mathrm{~cm}$ which already contains 10 $15 \mathrm{ml}$ of RPMI media. Change of culture media is done after 2-3 days.

\section{HeLa . Cell Cytotoxicity Test}

HeLa cells were observed using an interved microscope, then subcultured if heLa cells were attached and $80-90 \%$ confluent. Furthermore, making doses of 2000, 1000, 500, 250, and $125 \mathrm{ppm}$. Take the heLa cell culture flask into the LAF and withdraw all the media in the flask. Then, put each dose into each well with 3 repetitions. Incubate for 24 hours at $37^{\circ} \mathrm{C}$ with $5 \% \mathrm{CO} 2$ humidity for 24 48 hours. Discard the cell media and add 50$100 \mu \mathrm{l}$ of MTT reagent to each well, then incubate for 4 hours. Check the condition of

\section{RESULT AND DISCUSSION}

\section{Extract Yield Research Results}

Extract yield is obtained from the percentage of raw materials that can be used as total raw materials. The higher the yield value produced, the more raw materials that can be utilized (Musa et al., 2017). the cells using an interved microscope, if formazan is clearly formed add a stopper solution of $10 \mu \mathrm{l}$ SDS $10 \%$ in $0.1 \mathrm{~N} \mathrm{HCl}$. Then read the absorbance value of each well using an Elisa reader with a wavelength of $595 \mathrm{~nm}$. Calculate the percentage of live cells and analyze the $\mathrm{IC}_{50}$ value.

$\%$ live cells $=\frac{O D \text { Treatment }-O D \text { Media }}{\text { OD Cell control-media }} \times 100 \%$

Information :

OD = Optical Density (Absorbance value)

\section{i) Liquid Chromatography Mass Spectrophotometry (LC-MS) Analysis}

Sonneratia alba leaf extract as much as $1 \mathrm{ml}$, dissolved in $1 \mathrm{ml}$ of $95 \%$ methanol and $1 \mathrm{ml}$ of $0.3 \%$ acetic acid. Take a solution of $0.01 \mathrm{ml}$ injected into the LC-MS system at a rate of 0.3 $\mathrm{ml} /$ minute. Then the solution is pumped for $10-$ 15 minutes and enters the selector column. The molecular weight was detected using a mass spectrophotometer pumped for 10-15 minutes

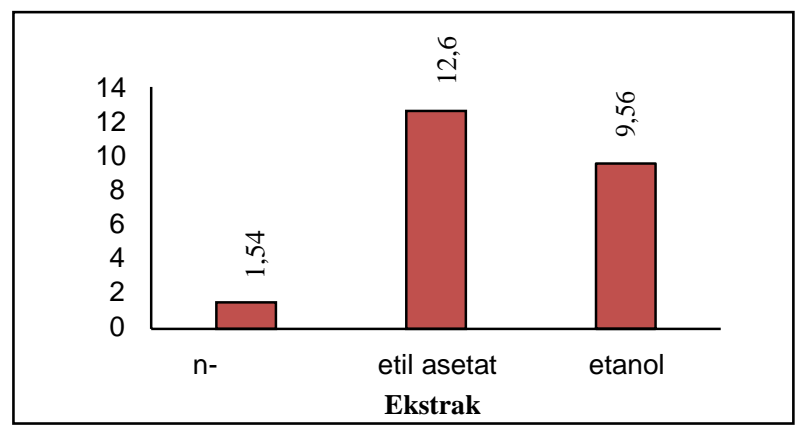

Figure 1. Extract Yield Graph 
The highest yield of Sonneratia alba leaf extract was $12.6 \%$ in ethyl acetate extract and the lowest yield was $1.54 \%$ in n-hexane extract. Ethyl acetate is included in a solvent that has semipolar properties, so it is able to attract compounds with polar and nonpolar properties. Ethyl acetate will extract active compounds that are soluble in intracellular and extracellular fluids in plants (Putri et al., 2013). Factors that can affect the yield value include the extraction method used, sample particle size, storage conditions and time, the length of the extraction process, the ratio of the number of solvents and the number of samples, and the use of the type of solvent (Satriani \& Burhanuddin, 2018).

\section{Extract Moisture Content}

Moisture content is the water content contained in a material expressed as a percent. Water content testing is carried out to determine the shelf life of a material, so as to avoid material damage due to fungal and enzyme activity (Gazali et al., 2020).

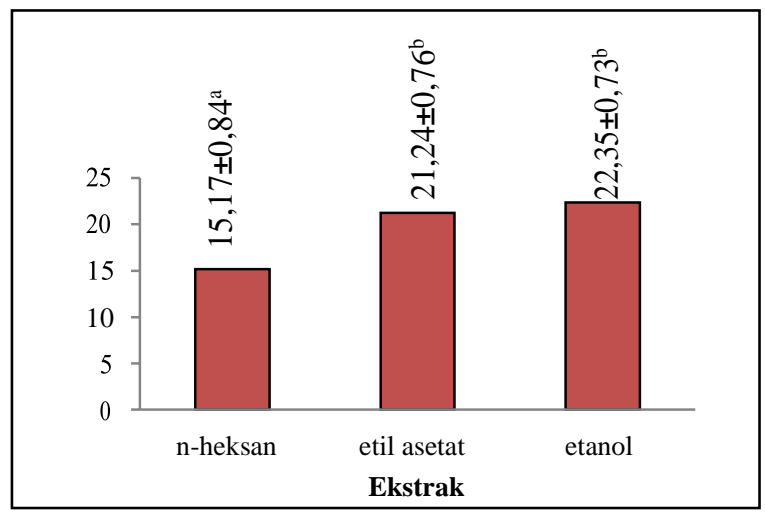

Figure 2. Graph of Extract Moisture Content

The result of the highest water content of Sonneratia alba leaf extract was in the ethanol extract of $22.35 \pm 0.73 \%$, while the lowest water content was found in the n-hexane extract of
$15.17 \pm 0.84 \%$. The results of the analysis using ANOVA (Analysis of variance) showed that the extract treatment was significantly different $(\mathrm{p}<0.05)$ with respect to water content. Furthermore, the Tukey test was performed and the results of the n-hexane extract were significantly different from the ethyl acetate and ethanol extracts.

The water content of Sonneratia alba leaf extract increased. According to Yulianti et al., (2014), stated that the higher the water content in the ethanol extract was influenced by the length of the extraction time. The longer the extraction time, the more water content is produced. Each solvent has volatile properties. In addition, the ethyl acetate solvent has a solubility in water of $8.7 \%$ which indicates the concentration of ethyl acetate used will affect the water content of a material.

\section{Phytochemicals}

Phytochemical test is a qualitative test used to determine the bioactive compounds contained in Sonneratia alba leaves.

Table 2. Phytochemical Test

\begin{tabular}{lccc} 
Bioactive & \multicolumn{3}{c}{ Extract } \\
\cline { 2 - 3 } Compound & n-heksan & $\begin{array}{r}\text { ethyl } \\
\text { acetate }\end{array}$ & $\begin{array}{c}\text { etha } \\
\text { nol }\end{array}$ \\
\cline { 2 - 3 } Alkaloid & + & + & + \\
Saponin & - & - & - \\
Steroid/ & + & + & + \\
triterpenoid & + & - & + \\
Flavonoid & + & & + \\
Tanin & - & & +
\end{tabular}


Phytochemical test results showed that Sonneratia alba mangrove leaf extract contains alkaloids, steroids/triterpenoids, flavonoids (in nhexane and ethanol extracts), and tannins (in ethyl acetate and ethanol extracts). Bioactive compounds have the ability for human health, among others, as a source of antioxidants, antibacterial, anti-inflammatory, and anticancer (Firdiyani et al., 2015).

\section{Toxicity}

Toxicity test aims to determine the ability of a compound as a poison by knowing the toxic level of the plant (Puspitasari et al., 2018). The parameter used in the toxicity test is the $\mathrm{LC}_{50}$ value.

Figure 3. Toxicity Test Graph

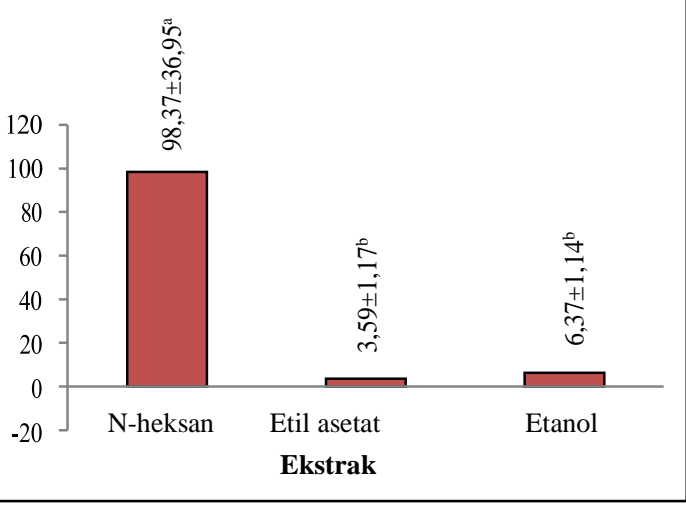

The results of the toxicity test of Sonneratia alba leaf extract were highest in n-hexane extract of $98.37 \pm 36.95 \mathrm{ppm}$ and the lowest was found in ethyl acetate extract of $3.59 \pm 1.17 \mathrm{ppm}$. Based on the results of the ANOVA analysis (Analysis of variance) showed that the extract treatment was significantly different $(\mathrm{p}<0.05)$ with respect to the $\mathrm{LC}_{50}$ value. Furthermore, Tukey's further test was carried out and showed the results that the nhexane extract was significantly different from the ethyl acetate and ethanol extracts.
The lower the $\mathrm{LC}_{50}$ value, the higher the level of toxicity of a material. This is because the ethyl acetate solvent is able to attract more bioactive compounds. Based on the phytochemical test produced, the compounds contained in the ethyl acetate extract include alkaloids, steroids/triterpenoids, and tannins. These compounds have toxic properties that have the ability to kill Artemia salina larvae which work as stomach poisons (Rohmah et al., 2019).

\section{Total Phenol}

Total phenol contains phenolic compounds in which there is a hydroxy group and acts as a free radical scavenger. (Niken et al., 2019).

Figure 4. Graph of Total Phenol

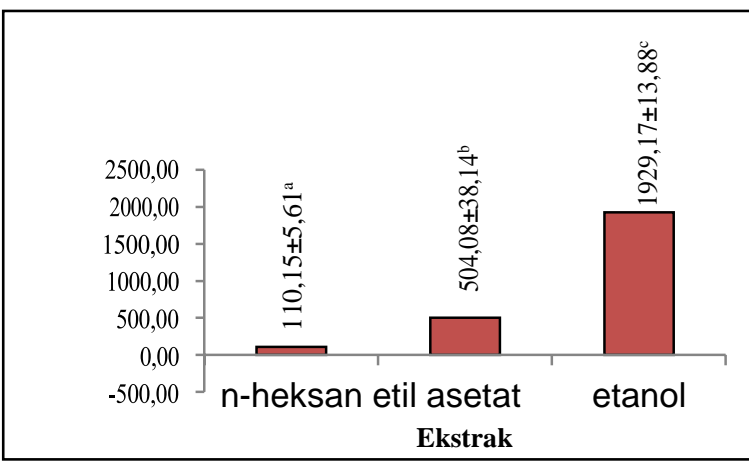

The highest yield was found in the ethanol extract of $1929.17 \pm 13.88 \mathrm{mg} / \mathrm{g}$ GAE, while the lowest yield was found in the n-hexane extract of $110.15 \pm 5.61 \mathrm{mg} / \mathrm{g}$ GAE. The results of the analysis using ANOVA (Analysis of variance) showed that the extract treatment was significantly different $(\mathrm{p}<0.05)$ with respect to total phenol. Then proceed with the Tukey test and show the results between extracts have different values. The total phenol produced by Sonneratia alba leaf extract has increased because the phenol content in plants will increase along 
with the increase in the polarity of the solvent used (non polar, semi polar, and polar) (Yanuarti et al., 2017).

\section{HeLa . Cell Cytotoxicity}

Cytotoxicity test aims to determine the effect of the toxicity of ethyl acetate extract of Sonneratia alba leaves on heLa cells.

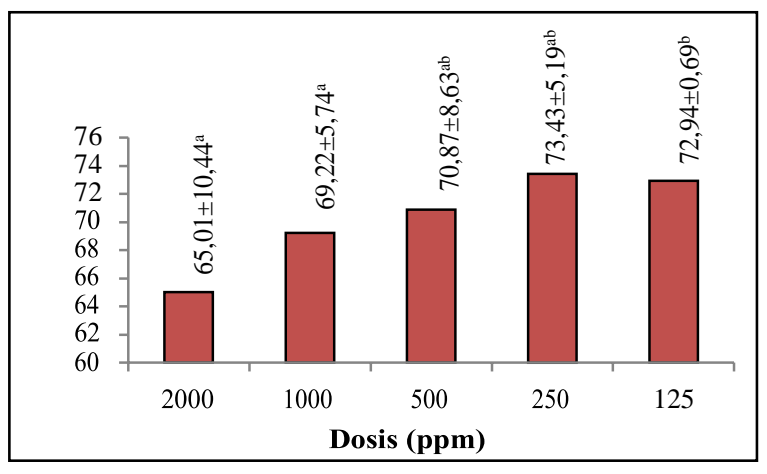

Figure 5. Graph of HeLa Vi Cell Viability

The highest value was found at a dose of $250 \mathrm{ppm}$ of $73.43 \pm 5.19 \%$ and the lowest was at a dose of $2000 \mathrm{ppm}$ of $72.94 \pm 0.69 \%$. The results of the analysis using ANOVA (Analysis of variance) showed that the dose treatment was significantly different $(\mathrm{p}<0.05)$ on the viability of heLa cells. Then continued with the Tukey test and the results obtained between treatments had different values.

From the resulting data, the viability of heLa cells increased with increasing the dose given. This is because at the time of testing, MTT reagent was added and formazan crystals were formed. Living cells will secrete dehydrogenase enzymes and form formazan crystals. Then the formazan will come out and be purple. The intensity of the purple color formed will be directly proportional to the number of cells that are still alive. Thus, the higher the intensity of the purple color formed, the more the number of living cells (Rahardhian \& Utami, 2016). The parameter used in the cytotoxicity test is the $\mathrm{IC}_{50}$ value.

\begin{tabular}{|c|c|c|}
\hline $\begin{array}{l}\text { Dose } \\
\text { (ppm) }\end{array}$ & $\%$ living cell & $\operatorname{IC50}(\mu \mathrm{g} / \mathrm{mL})$ \\
\hline 2000 & 65,01 & \\
\hline 1000 & 69,22 & \\
\hline 500 & 70,87 & 478,630 \\
\hline 250 & 73,43 & \\
\hline 125 & 72,43 & \\
\hline
\end{tabular}

The IC50 value will indicate an inhibition of heLa cell activity by $50 \%$ and indicate the level of toxicity of a material. The higher the $\mathrm{IC}_{50}$ value, the lower the level of toxicity of a material (Haryoto et al., 2013). The $\mathrm{IC}_{50}$ value produced by Sonneratia alba leaf extract was $478.630 \mathrm{~g} / \mathrm{ml}$. So that the leaf extract of Sonneratia alba is included in the category of being quite active against heLa cells. The activity produced is influenced by the bioactive compounds contained, such as alkaloids, steroids/triterpenoids, and tannins. These compounds will cause toxic effects on HeLa cells by inhibiting cell growth. So that it has potential as an anticancer (Sahid et al., 2013).

\section{Liquid Chromatography Mass Spectrometry (LC-MS)}

LCMS testing aims to identify bioactive compounds found in plants. The identification results of the biactive compounds will be displayed in the form of a chromatogram with a peak at a certain retention time. The results of the identification of the bioactive compounds of Sonneratia alba leaf extract produced the 
bioactive compounds diosmetin, caffeine, and turmerone. Diosmetin compounds can be used as anticancer, because they produce anticarcinogenic effects by increasing apoptosis and inhibiting cell proliferation (Martiati et al., 2018). Caffeine compounds can be used as anticancer, because they are included in alkaloid compounds that can selectively increase apoptosis in cancer cells (Ayuningtyas et al., 2017). Turmerone compounds contain antioxidants that can ward off free radicals. The higher the turmerone compound, the greater the antioxidants in the plant (Islamadina et al., 2020).

Table 4. Alleged Compound Ethyl Acetate Extract of Sonneratia alba . Leaf

\begin{tabular}{lcccc}
\hline Treatment & $\begin{array}{l}\text { Time } \\
\text { Retention }\end{array}$ & $\begin{array}{l}\text { Mass } \\
\text { Compoun } \\
\text { d }\end{array}$ & Alleged Compound & $\begin{array}{c}\text { Molecular } \\
\text { Formula }\end{array}$ \\
\hline \multirow{3}{*}{ Esktrak etil asetat } & 8.70 & 300.363 & Diosmetin & $\mathrm{C}_{16} \mathrm{H}_{12} \mathrm{O}_{6}$ \\
& 10.77 & 194.191 & Caffeine & $\mathrm{C}_{8} \mathrm{H}_{10} \mathrm{~N}_{4} \mathrm{O}_{2}$ \\
& 11.45 & 216.319 & Turmerone & $\mathrm{C}_{15} \mathrm{H}_{20} \mathrm{O}$ \\
\hline
\end{tabular}

\section{CONCLUSION}

The $\mathrm{IC}_{50}$ value of the ethyl acetate extract of the leaves of Sonneratia alba was 478.630 $/ \mathrm{g} / \mathrm{ml}$, indicating that the ethyl acetate extract had potential as an anticancer. The lowest cell viability was produced at a dose of $2000 \mathrm{ppm}$ of $72.94 \pm 0.69 \%$. Variations in the dose of ethyl

\section{REFERENCES}

Ariani, S. (2015). Stop kanker. Yogyakarta. Istiana Media

Ayuningtyas, D. D. R., Nurahmanto, D., \& Rosyidi, V. A. (2017). Optimasi komposisi polietilen glikol dan lesitin sebagai kombinasi surfaktan pada sediaan nanoemulsi kafein. E-Jurnal Pustaka Kesehatan, 5(1), 157-163.

Firdiyani, F., Agustini, T. W., \& Ma'ruf, W. F. (2015). Ekstraksi senyawa bioaktif sebagai antioksidan alami Spirulina plantesis segar dengan pelarut yang acetate extract of Sonneratia alba leaves given to heLa cells affected cell viability. The alleged bioactive compounds contained in the ethyl acetate extract of the leaves of Sonneratia alba include diosmetin, caffeine, and turmerone.

berbeda. Jurnal Pengolahan Hasil Perikanan, 18(1), 28-37.

Gazali, M., Nurjanah, Ukhty, N., Nurdin, M., \& Zuriat. (2020). Skrining senyawa bioaktif daun perepat (Sonneratia alba J. E. Smith) sebagai antioksidan asal pesisir Kuala Bulon Aceh Barat. JPHPI, 23(2), 401-411.

Gustiana, D., Dewi, Y. I., \& Nurchayati, D. (2014). Faktor-faktor yang berhubungan dengan perilaku pencegahan kanker serviks pada wanita usia subur. Jom Psik, 
1(2), 1-8.

Harwoko, \& Utami, E. D. (2010). Aktivitas sitotoksik fraksi n-heksan : kloroform dari ekstrak methanol kulit batang mangrove (Rhizopora mucronata)pada sel kanker myeloma. Majalah Obat Tradisional, 15(2), 51-55.

Haryoto, Muhtadi, Indrayudha, P., Azizah, T., \& Suhendi, A. (2013). Aktivitas sitotoksik ekstrak etanol tumbuhan sala (Cynometra ramiflora Linn) terhadap sel heLa, T47D, dan WiDR. Jurnal Penelitian Saintek, 18(2), 21-28.

Islamadina, R., Chan, A., \& Rohman, A. (2020). Aplikasi kemometrika dalam mengelompokkan dan menentukan korelasi senyawa mudah menguap terhadap aktivitas antioksidan minyak atsiri kunyit (Curcuma longa). Journal of Food and Pharmaceutical Sciences, 8(2), 227-241.

Mahfur. (2016). Uji sitotoksik fraksi etil asetat ekstrak etanol akar pasak bumi (Eurycoma longifolia jack) terhadap sel kanker T47D dengan metode 3-(4,5 dimetitiazol $\quad-2 \quad-$ il)-2,5 difenil tetrazolium bromide (MTT). Jurnal Ilmu Pengetahuan dan Teknologi, 30(2), 5763.

Martiati, T., Mumpuni, E., Mulatsari, E., \& Maryanto, K. (2018). Analisis selektivitas senyawa turunan diosmetin sebagai antioksidan baru dengan menggunakan metode Molecular Docking. 10(1), 362-370.
Musa, W. J. A., Duengo, S., \& Tahir, R. H. (2017). Senyawa triterpenoid dari tumbuhan mangrove (Sonneratia alba). Jurnal ITEKIMIA, 1(1), 36-45.

Musa, W. J. A., Nurhayati, B., Boima, S., \& Saromon, S. (2019), Triterpenoid coumpound from methanol extract of mangrove leaves (Sonneratia alba) and anti-cholestrol activity test. Jurnal Pendidikan Kimia, 11(1), 18-23.

Niken, Putri, I. L. E., \& Gusti, F. R. (2019). Uji senyawa fitokimia buah pedada merah (Sonneratia caseolaris) dikawasan hutan mangrove mangguang kota Pariaman. Jurnal Kesehatan Saintika Meditory, 1(2), 44-49.

Puspitasari, E., Rozirwan, \& Hendri, M. (2018). Uji toksisitas menggunakan metode Brine Shrimp Lethality Test (Bsit) pada ekstrak mangrove (Avicennia marina, Rhizopora mucronata, Sonneratia alba, dan Chylocarpus granatum). Jurnal Biologi Tropis, 18(1), 91-103.

Putri, W. S., Warditiani, N. K., \& Larasanty, L. P. F. (2013). Skrining fitokimia ekstrak etil asetat kulit buah manggis (Gracinia mangostana L.). Journal Pharmacon, 2(4), 56-60.

Rahardhian, M. R. R., \& Utami, D. (2016). Uji sitotoksik dan antiploriferasi ekstrak eter daun binahong (Andredera cordifolia (Tenore) Streen.) terhadap sel HeLa. Media Farmasi Indonesia, 13(1), 12841292 
Rio, S., \& Suci, E. S. T. (2017). Presepsi tentang

kanker serviks dan upaya prevensinya pada perempuan yang memiliki keluarga dengan riwayat kanker. Jurnal Kesehatan Reproduksi. 4(3), 159-169.

Rohmah, J., Rini, C. S., \& Wulandari, F. E. (2019). Uji aktivitas sitotoksik ekstrak selada merah (Lactuca sativa var. Crispa) pada berbagai pelarut ekstraksi dengan metode BSLT (Brine Shrimp Lethality Test). Jurnal Kimia Riset, 4(1), 18-32.

Sahid, A., Pandiangan, D., Siahaan, P., \& Rumondor, M. J. (2013). Uji sitotoksisistas ekstrak metanol daun sisik naga (Drymoglossum piloselloides Presl.) terhadap sel leukemia P388. Jurmal MIPA, 2(2), 94-99.

Satriani, G. I., \& Burhanudi, I. (2018). Sediaan krim tabir surya berbasis bahan baku lokal hutan mangrove (Sonneratia alba) Kota Tarakan. 1-10.

Yanuarti, R., Nurjanah, Anwar, E., \& Hidayat, T. (2017). Profil fenolik dan aktivitas antioksidan dari ekstrak rumput laut Turbinaria conoides dan Eucheuma cottonii. Jurnal Pengolahan Hasil Perikanan Indonesia, 20(2), 230-237.

Yulianti, D., Susilo, B., \& Yulianingsih, R. (2014). Pengaruh lama ekstraksi dan konsentrasi pelarut etanol terhadap sifat fisika-kimia ekstrak daun stevia (Stevia rebaudiana Bertoni $\mathrm{M}$ ) dengan metode Microwave Assisted Extraction (MAE). Jurnal Bioproses Komoditas Tropis, 2(1), 